\title{
Incidence of non-melanocytic skin cancer treated in Australia
}

\author{
GRAHAM G GILES， ROBIN MARKS， PETER FOLEY
}

\begin{abstract}
In 1985, as part of a national random household omnibus survey by a market research company, 30976 Australians (mostly of European origin) were asked whether they had ever been treated by a doctor for skin cancer. The treating doctor or hospital was then approached for confirmation of the diagnosis of all those people who claimed to have been so treated within the past 12 months. Demographic data were also collected, permitting analysis by age, sex, country of birth, current residence, and skin reaction to strong sunlight.

Melanomas accounted for less than $5 \%$ of the tumours treated. The world standardised incidence of melanoma was 19/100000 population. The standardised incidence of treated nonmelanocytic skin cancer in Australia was estimated to be $823 / 100000$. The standardised rates for basal cell carcinoma and squamous cell carcinoma were 657 and $166 / 100000$ respectively, yielding a standardised rate ratio of about $4: 1$. Standardised rates based on medically confirmed cases only were 555,443 , and $112 / 100000$ for all non-melanocytic skin cancers, basal cell carcinomas, and squamous cell carcinomas respectively.

Significant differences and trends in incidence were noted with respect to age and sex. Rates in men were higher than those in women but significantly so only after the age of 60 . People born in Australia had a rate of $936 / 100000$ compared with $402 / 100000$ in British migrants. Rates for non-melanocytic skin cancer showed a gradient with respect to latitude within Australia. The rate in people residing north of $29^{\circ} \mathrm{S}$ was $1242 / 100000$ compared with a rate of $489 / 100000$ in those living south of $37^{\circ} \mathrm{S}$. A person's skin reaction to strong sunlight was a good indicator of the risk of skin cancer, tanning ability being inversely related to its incidence. The rate in those who always burnt and never tanned when exposed to strong sunlight was $1764 / 100000$ compared with a rate of $616 / 100000$ in those who always tanned and never burnt.
\end{abstract}

Anti-Cancer Council of Victoria, Carlton South, 3053, Australia GRAHAM G GILES, PHD, director, cancer epidemiology centre ROBIN MARKS, $M B$, MPH, director, education unit PETER FOLEY, medical student

Correspondence to: Dr Giles.
These findings have important implications for public education programmes in relation to exposure to sunlight in Australia.

\section{Introduction}

Non-melanocytic skin cancers are common in many parts of the world but accurate reports of their frequency are rare. Non-melanocytic skin cancer presents difficulties for cancer registration as many cases are treated in doctors' surgeries by simple excision, curettage, or cryosurgery. Cancer registries that record non-melanocytic skin cancer depend entirely on that variable proportion of tumours that are histologically verified and then notified. There have been few epidemiological studies of these lesions at a community level and there has never been a population wide survey of their incidence in Australia, which purportedly has the highest rates of skin cancer in the world. . $^{1-5}$

Because of the heightened risk to Australians, most of whom are of European origin (Aborigines account for only about $1 \%$ of the population), education campaigns have been carried out to try to decrease skin cancer by promoting behavioural changes with respect to exposure to the sun. Without routine monitoring of non-melanocytic skin cancer in the community the only evaluation of these programmes has been by assessment of behavioural end points. It has also been impossible to examine trends in incidence or to estimate the costs of non-melanocytic skin cancer to the health care system. We therefore decided to conduct a national survey to obtain baseline incidence data and to repeat similar surveys at five year intervals in order to assess trends. The aims of the baseline survey were to determine the yearly incidence of skin cancer treated in Australia and to investigate the effect of variables such as age, sex, occupation, residence, country of birth, and skin reaction to strong sunlight on its development.

\section{Population and methods}

The study population comprised the resident population of Australia in 1985 aged 14 or over. In order to conduct economically a survey of a representative sample of a population occupying a geographical area comparable to the United States we decided to use a commercial market research organisation which conducts face to face interviews with a 
representative sample of over 1100 people aged over 14 each week across Australia. This omnibus survey canvasses political opinions, consumer preferences, and smoking and drinking habits and also collects information necessary for calculating rates by age, sex, and other demographic variables.

The following questions were added to the omnibus survey questionnaire:

“(1) Have you, yourself, ever been treated by a doctor for skin cancer?

(2) How many separate skin cancers have you had treated by a doctor?

(3) How many weeks, months, or years is it since you were last treated by a doctor for skin cancer?" If the respondent admitted to having been treated for skin cancer in the past 12 months (the incidence period) he or she was asked to give the name and address of the doctor or hospital, or both. The respondent was then asked to sign a form giving consent for the researchers to contact the doctor or hospital to obtain further details about the skin cancer. All respondents answering affirmatively to the question on skin cancer and the first 4000 respondents in the survey irrespective of their professed skin cancer state were asked an additional question about their skin reaction to strong sunlight: "Looking at the card, which one line best describes what happens to your skin when you are exposed to strong sunshine? (1) Always burn, never tan. (2) Burn first, then tan. (3) Just tan and never burn."

Letters were sent to the treating doctor or hospital of each person who stated that he or she had been treated in the past 12 months. The letters explained the nature of the survey and asked for confirmation of diagnostic details. These included the date of treatment, clinical diagnosis of the lesion treated, and whether the lesion had been confirmed histologically. The site of the lesion was indicated on body maps derived from those used in the International Agency for Research on Cancer's collaborative study of malignant melanoma (C Muir, Lyon, personal communication). For geographical analysis Australia was divided into three areas by two parallels of latitude. Parallels $29^{\circ} \mathrm{S}$ and $37^{\circ} \mathrm{S}$ were chosen because they were the most convenient with reference to the place of residence coding used for the survey-that is, in electoral divisions. The 29th parallel represents the Queensland-New South Wales border and made it possible to include all people in Queensland together.

Statistics-Cross tabulations were performed by using the CROSSTABS subroutine from the statistical package for the social sciences. ${ }^{6}$ Predicted rates were obtained by fitting a quadratic logistic regression model to the observed age, sex, histological type, medically confirmed specific rates using the generalised linear interactive modelling package. ${ }^{7}$ Incidence was calculated for clinically confirmed tumours and also adjusted to account for a proportion of cases with incomplete information (see below). Age and sex specific rates were calculated by using the age divisions available from the survey (14-39, 40-49, 50-54, 55-59, 60-64, 65-69, $\geqslant 70$ years). Adjustment for age was conducted by using the world standard population ${ }^{8}$ aggregated to the above age strata. The occurrence of skin cancer in the unsurveyed group (ages 0-13) was assumed to be zero and rates were adjusted to the entire standard population. Differences between standardised incidence ratios were tested for statistical significance by Cochran's test. ${ }^{10}$

\section{Results}

Between 26 January and 8 September 1985, 30976 people were interviewed. There were $229(0.7 \%)$ who did not answer the questions on skin cancer, representing a $99 \cdot 3 \%$ positive response rate. Of the 30747 people who answered the question "Have you, yourself, ever been treated by a doctor for skin cancer?" 1179 responded affirmatively-that is, $3.8 \%$ of the total surveyed. Of these, $928(79 \%)$ both gave their doctor's name and address and signed the consent form permitting the doctor to release information. The remaining 251 either did not give details of their medical practitioner or hospital (187) or did not sign the consent form (64). Replies were received for 823 of the 923 patients whose doctors were contacted, representing a medical response for $70 \%$ of respondents who answered affirmatively about any treatment for skin cancer. Of the 823 patients whose medical practitioners or hospitals replied, the records'could not be found for 28. These patients had usually attended a main public hospital which had been asked to locate records for people with common surnames but had been given little additional information.

Full details were therefore available for 795 respondents $(67 \%$ of those who claimed that they had been treated for skin cancer in the past 12 months). Of these, however, only 245 (31\%) were found actually to have had skin cancers treated in the past 12 months. Ninety nine respondents had been treated more than 12 months before, six had had cancer elsewhere, and two had not had skin cancer themselves but had given details of cancer in their spouses. The remaining 443 respondents (56\%) who had not been treated for skin cancer at any time included 318 treated for solar keratoses, 20 with seborrhoeic keratoses, 16 with keratoacanthoma, and 12 with Bowen's disease. Other conditions erroneously thought to be skin cancer by the respondent included solar elastosis, dermal scarring, intradermal naevi, psoriasis, pityriasis versicolour, warts, erythema multiforme, postinflammatory sclerosis, granuloma, lentigo, haemangioma, and chondrodermatitis nodularis chronica helicis. Table I summarises the response rates and structure and stages of the survey. The 384 respondents with incomplete information gathered between stages (3) and (7) did not $\stackrel{\mathbb{Q}}{2}$ differ significantly in demographic features from the total survey population. $\subseteq$

TABLE I-Response rates and structure and stages of survey

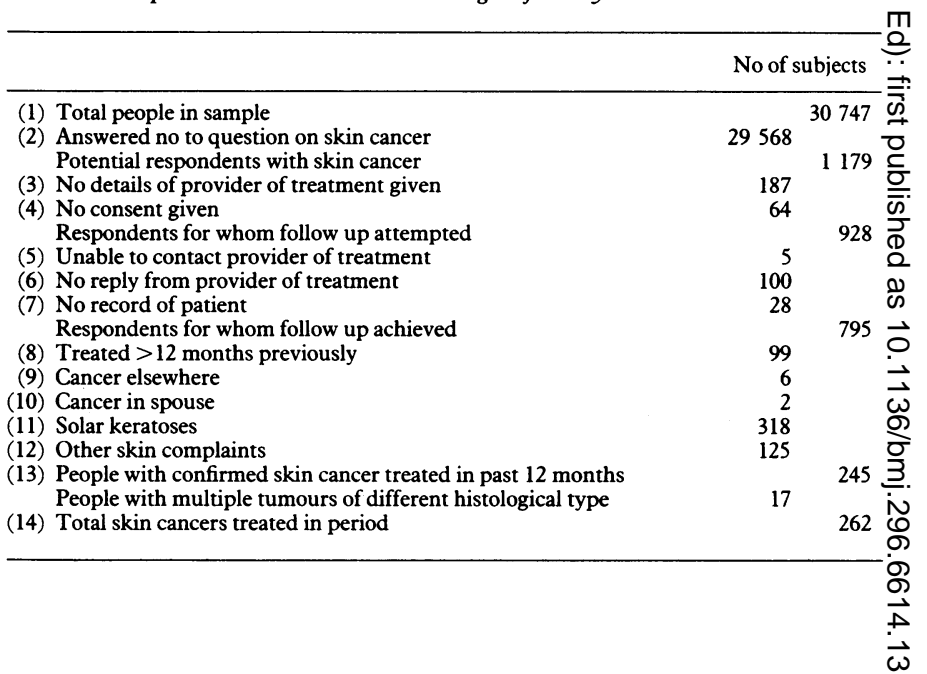

We considered that the medically confirmed "incident" cases should $\mathrm{O}$ form the basis of minimum incidence estimates but that a proportion of ${ }_{N}$ the 384 cases with missing information were likely to be valid and that the minimum estimates should be adjusted to reflect the probable contribution $\frac{2}{5}$ from the cases with missing data and also provide a maximum estimate. Each cell was therefore multiplied by the fraction of potential cases for which diagnosis was unconfirmed $(1179 / 795=1 \cdot 483)$. Also included were the $17 \vec{\sim}$ multiple tumours of different histological type diagnosed in the period. Multiple squamous cell or basal cell carcinomas were counted $\varnothing^{\circ}$ only once. Altogether the 245 respondents with medically confirmed disease had 262 cancers. After the exclusion of eight melanomas and one dermatofibrosarcoma 253 medically confirmed non-melanocytic skin cancers were available for analysis.

Age and sex specific rates and anatomical distributions were analysed with $\frac{\mathscr{D}}{\mathscr{D}}$ reference to confirmed cancers only. All other results were based on $\varnothing$

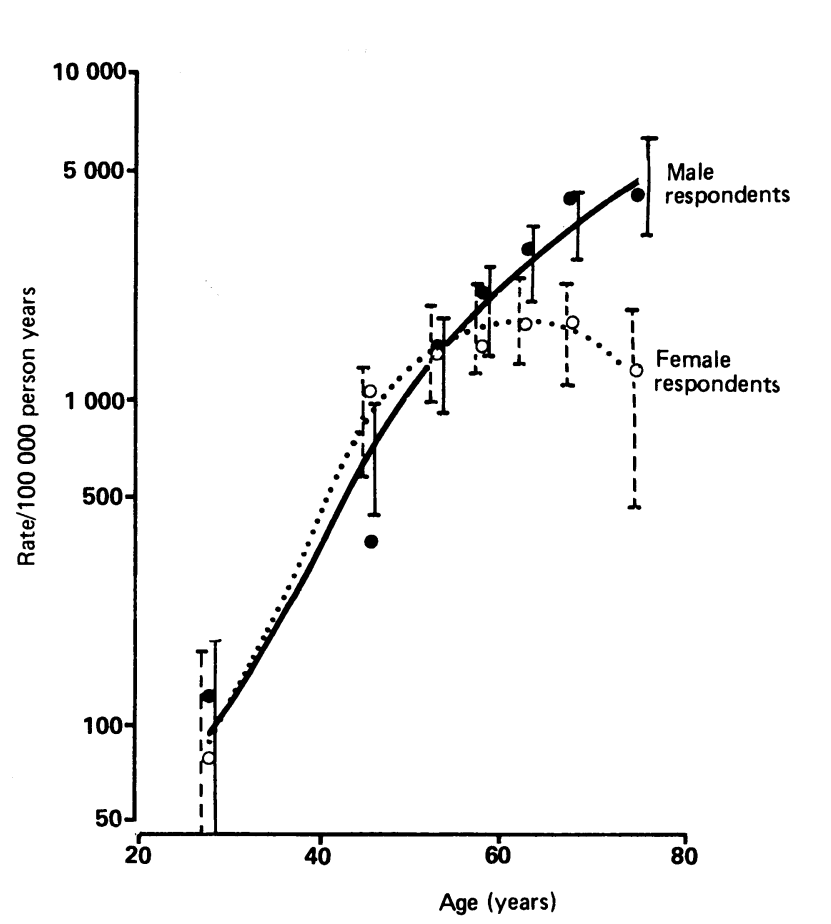
Incidence of medically confirmed non-melanocytic skin cancer stratified by age
and sex. Bars are $99 \%$ confidence limits. 
TABLE II-Medically confirmed non-melanocytic skin cancers stratified by age, sex, and histological type

\begin{tabular}{|c|c|c|c|c|c|c|c|c|c|c|c|c|}
\hline \multirow[b]{2}{*}{$\underset{(\text { years) }}{\text { Age }}$} & \multicolumn{4}{|c|}{ Male respondents } & \multicolumn{4}{|c|}{ Female respondents } & \multicolumn{4}{|c|}{ All respondents } \\
\hline & Sample & $\begin{array}{c}\text { Basal } \\
\text { cell } \\
\text { carcinoma }\end{array}$ & $\begin{array}{l}\text { Squamous } \\
\text { cell } \\
\text { carcinoma }\end{array}$ & $\begin{array}{c}\text { Total } \\
\text { non-melanocytic } \\
\text { cancers }\end{array}$ & Sample & $\begin{array}{c}\text { Basal } \\
\text { cell } \\
\text { carcinoma }\end{array}$ & $\begin{array}{l}\text { Squamous } \\
\text { cell } \\
\text { carcinoma }\end{array}$ & $\begin{array}{l}\text { Total } \\
\text { non-melanocytic } \\
\text { cancers }\end{array}$ & Sample & $\begin{array}{c}\text { Basal } \\
\text { cell } \\
\text { carcinoma }\end{array}$ & $\begin{array}{l}\text { Squamous } \\
\text { cell } \\
\text { carcinoma }\end{array}$ & $\begin{array}{c}\text { Total } \\
\text { non-melanocytic } \\
\text { cancers }\end{array}$ \\
\hline $\begin{array}{l}14-39 \\
40-49 \\
50-54 \\
55-59 \\
60-64 \\
65-69 \\
\geqslant 70\end{array}$ & $\begin{array}{r}8152 \\
2175 \\
857 \\
900 \\
934 \\
699 \\
1083\end{array}$ & $\begin{array}{r}10 \\
5 \\
10 \\
16 \\
20 \\
21 \\
35\end{array}$ & $\begin{array}{r}0 \\
3 \\
2 \\
3 \\
7 \\
8 \\
11\end{array}$ & $\begin{array}{r}10 \\
8 \\
12 \\
19 \\
27 \\
29 \\
46\end{array}$ & $\begin{array}{r}8822 \\
2393 \\
1027 \\
899 \\
1000 \\
696 \\
1110\end{array}$ & $\begin{array}{r}7 \\
19 \\
12 \\
11 \\
15 \\
8 \\
13\end{array}$ & $\begin{array}{l}0 \\
6 \\
2 \\
2 \\
2 \\
4 \\
1\end{array}$ & $\begin{array}{r}7 \\
25 \\
14 \\
13 \\
17 \\
12 \\
14\end{array}$ & $\begin{array}{r}16974 \\
4568 \\
1 \quad 884 \\
1 \quad 799 \\
1934 \\
1395 \\
2193\end{array}$ & $\begin{array}{l}17 \\
24 \\
22 \\
27 \\
35 \\
29 \\
48\end{array}$ & $\begin{array}{r}0 \\
9 \\
4 \\
5 \\
9 \\
12 \\
12\end{array}$ & $\begin{array}{l}17 \\
33 \\
26 \\
32 \\
44 \\
41 \\
60\end{array}$ \\
\hline Total & 14800 & 117 & 34 & 151 & 15897 & 85 & 17 & 102 & 30747 & 202 & 51 & 253 \\
\hline Rate* $^{\star}$ & & 510 & 147 & 657 & & 377 & 78 & 455 & & 443 & 112 & 555 \\
\hline
\end{tabular}

$\star$ Rate/100000 person years standardised to world population.

confirmed estimates adjusted to take into account respondents with unconfirmed diagnoses. All tests of statistical significance were based on the medically confirmed diagnoses. Table II presents the survey results in terms of the absolute numbers of respondents of each age and sex and in each histological subgroup of cancer and including the sample base populations. The figure shows the fitted age incidence curves and $99 \%$ confidence limits for all non-melanocytic skin cancers in each sex. Table III shows the anatomical distribution of tumours and tables IV-VI the rates of non-elanocytic skin cancer stratified by sex and latitude, country of birth, and reaction to strong sunlight.

TABLE III-Number (percentage) of non-melanocytic skin cancers stratified by site and histological type

\begin{tabular}{lcccrc}
\hline & Head and neck & Arm & Leg & Trunk & Total \\
\hline $\begin{array}{l}\text { Squamous cell carcinoma } \\
\text { Basal cell carcinoma }\end{array}$ & $22(43)$ & $11(22)$ & $11(22)$ & $7(14)$ & $51(100)$ \\
\hline Total & $134(66)$ & $16(8)$ & $16(8)$ & $36(18)$ & $202(100)$ \\
\hline
\end{tabular}

TABLE IV-Non-melanocytic skin cancer rates ${ }^{\star}$ stratified by latitude and sex

\begin{tabular}{lccc}
\hline \multicolumn{1}{c}{ Latitude } & Male respondents & Female respondents & Total \\
\hline$<29^{\circ} \mathrm{S}$ & 1476 & 1004 & 1242 \\
$29^{\circ}-37^{\circ} \mathrm{S}$ & 970 & 699 & 841 \\
$>37^{\circ} \mathrm{S}$ & 566 & 424 & 489 \\
\hline
\end{tabular}

$\star$ Rates $/ 100000$ person years standardised to world population and adjusted for respondents with unconfirmed diagnoses (see text).

The world standardised incidence of melanoma was $19 / 100000$ population. The standardised incidence of treated non-melanocytic skin cancer was $555 / 100000$. Standardised rates for basal cell carcinoma and squamous cell carcinoma were 443 and $112 / 100000$ respectively, yielding a standardised rate ratio for basal cell to squamous cell carcinoma of around 4:1. After adjustment for respondents with missing data the rates increased to 823 , 657 , and 166/100000 for all non-melanocytic skin cancers, basal cell carcinomas, and squamous cell carcinomas respectively. Cancers were predominantly located on the head and neck $(62 \% ; 156 / 253)$, most of which $(86 \% ; 134 / 156)$ were basal cell carcinomas. Of the $54(21 \%)$ tumours on the limbs, $32(59 \%)$ were basal cell carcinomas. Only 43 tumours (17\%) occurred on the trunk, of which seven (16\%) were squamous cell carcinomas.

Significant differences and trends in incidence were noted with respect to age and sex. Overall rates were higher in male respondents. The figure shows that the $99 \%$ confidence intervals for the fitted estimates overlapped until after age 60 , the difference being significant only from age 65 onwards. Australian born subjects had higher age standardised rate ratios (116) than either British (rate ratio $44 ; z=5 \cdot 4 ; p<0.001$ ) or total migrants (rate ratio 49; $z=6.7 ; p<0.0001)$. There was a gradient of increasing incidence with decreasing latitude. Standardised rate ratios for the lowest and highest latitudinal belts were 180 and 56 respectively $(z=12.6 ; p<0.0001)$. The
TABLE V-Non-melanocytic skin cancer rates ${ }^{\star}$ stratified by country of birth

\begin{tabular}{lccc}
\hline & Male respondents & Female respondents & Total \\
\hline Australia & 1120 & 769 & 936 \\
Britain & 538 & 223 & 402 \\
Other migrants & 418 & 277 & 375 \\
\hline Total & 986 & 661 & 823 \\
\hline
\end{tabular}

$\star$ Rates $/ 100000$ person years standardised to world population and adjusted for respondents with unconfirmed diagnoses (see text).

TABLE VI-Non-melanocytic skin cancer rates ${ }^{\star}$ stratified by reaction to strong sunlight

\begin{tabular}{lccc}
\hline & Male respondents & Female respondents & Total \\
\hline Burn and never tan & 2140 & 1387 & 1764 \\
Burn first, then tan & 1321 & 940 & 1130 \\
Just tan and never burn & 710 & 521 & 616
\end{tabular}

$\star$ Rates $/ 100000$ person years standardised to world population and adjusted for respondents with unconfirmed diagnoses (see text).

gradient was more pronounced in men than women. A person's skin reaction to strong sunlight appeared to be a good indicator of the risk of non-melanocytic skin cancer. The incidence was highest in those who always burnt and never tanned and lowest in those who just tanned and never burnt $\left(\chi^{2}=18 \cdot 6 ; \mathrm{df}=1 ; p<0 \cdot 0001\right)$.

\section{Discussion}

The incidence estimate for malignant melanoma of $19 / 100000$ population in 1985 was close to the incidence of $18 / 100000$ estimated for 1982 by Australian cancer registries. ${ }^{11}$ Given the rising trend in the incidence of melanoma the estimate is very close to what would have been expected and increases confidence in the survey's ability to predict the incidence of non-melanocytic skin cancer with precision. The rate of melanoma is thus a good yardstick of the survey's success.

With a yearly incidence of 823 skin cancers treated/100000 population, non-melanocytic skin cancer is the most common form of cancer in Australia. The true incidence is probably even higher because of the prevalence of untreated cancers in the community. The incidence of all cancers in Australia other than basal cell carcinoma and squamous cell carcinoma of the skin was 246/100 000 person years in 1982." Thus non-melanocytic skin cancer is more than three times $(3 \cdot 3: 1)$ as common as all other forms of cancer combined. The cumulative rate percentage up to age 75 is $30 \%$ for all other cancers and $67 \%$ for non-melanocytic skin cancer.

The incidence of non-melanocytic skin cancer in Australia is the highest reported in the world. The United States yearly adjusted incidence of non-melanocytic skin cancer among whites was 
$233 / 100000$ population in $1978^{12}$ - that is, less than a third of the rate found in this study. The highest United States non-melanocytic skin cancer rate of $539 / 100000$ person years in Dallas ${ }^{13}$ is a third less than the Australian rate. The rate reported in New Zealand ${ }^{14}$ is only a fifth and British rates ${ }^{15}$ only $3-5 \%$ of the Australian rate. A recent Swiss study reported rates between $5 \%$ and $6 \%$ of those reported here. ${ }^{16}$

The incidence of non-melanocytic skin cancer was significantly higher in men than women. This agrees with other surveys. ${ }^{16-19}$ Morison et al proposed that the increased risk among men was due to their greater likelihood of being employed out of doors and thus receiving more exposure to sunlight. ${ }^{20}$ These workers also noted that men have a lower minimal erythemal $\operatorname{dose}^{20}$ and therefore may be more susceptible to the carcinogenic effect of ultraviolet radiation, the cause of skin erythema. This has been reported only once and requires further investigation, as such a finding would be important for theories on the development of non-melanocytic skin cancer.

The decline in rates in women after the age of 50 is puzzling. It may have been due to inadequate sampling of women in this age group or it may be indicating a true difference between the sexes. If the difference is real then it may be reflecting either a biological or behavioural difference. Possibly postmenopausal skin cancer in women is aetiologically different from that occurring earlier in life. More probably women from earlier cohorts may have had less exposure to the sun than their younger counterparts or women after a certain age may avoid exposure. The incidence from the study of Scotto et al in the United States showed some decrement in older women, but this was confined to basal cell carcinoma. In both Queensland and Tasmania, where registration of non-melanocytic skin cancer has been attempted, rates continue to increase with age (L F Young, Tasmanian Cancer Registry, I Ring, Queensland Cancer Registry, personal communication, 1987). We therefore think that the difference in our series was probably due to sampling or response bias.

The increase in non-melanocytic skin cancer with age is likely to be due to two effects. As age increases so does the cumulative dose of ultraviolet radiation received by the skin. The second effect is that of aging itself, and it is almost impossible to separate the two. Carcinogenesis may require both an initiator and a promoter, ultraviolet radiation acting as both an initiator and promoter and age being a promoter. An interpretation of the increasing incidence with age is that the susceptibility of the population increases and that a smaller dose of ultraviolet radiation is necessary to initiate non-melanocytic skin cancer. If true this late stage dose effect has important implications for public education programmes.

The anatomical distribution of non-melanocytic skin cancers correlated well with the amount of exposure to sunlight. Most non-melanocytic skin cancers occurred on areas exposed to light, particularly the head and neck. Scotto and colleagues in comparing their 1971-2 and 1977-8 surveys found that the occurrence of basal cell carcinoma was becoming more common on the trunk. ${ }^{12}$ In our series $17 \%$ of non-melanocytic skin cancers were on the trunk, a far higher rate than the $6-7 \%$ reported for other white populations. ${ }^{21}$ There has been an increasing trend for Australians to develop an "all over tan," thus exposing more skin than previous generations and developing cancers on previously protected sites.

Many epidemiological studies have shown that the incidence of non-melanocytic skin cancer in susceptible populations increases with a decrease in latitude. ${ }^{12}{ }^{14}$ Our study confirms that the closer the population is to the equator the higher is the incidence of non-melanocytic skin cancer. The incidence in Queensland $\left(29^{\circ} \mathrm{S}\right)$ was more than twice $(2 \cdot 4: 1)$ the rate in Victoria and Tasmania $\left(37^{\circ} \mathrm{S}\right)$. This corresponds well with the estimates of ultraviolet radiation received in different parts of Australia calculated by Barton and Paltridge. ${ }^{22}$

Skin cancer was much less common among migrants when compared with people born in Australia. Holman and Armstrong proposed that people not exposed to severe sunlight early in life are less prone to develop melanoma. ${ }^{23}$ The comparison of Australian born people with British migrants suggests that this effect of early exposure may also be true of non-melanocytic skin cancer.
The shortcomings of the survey were, firstly, that the numbers of cancers detected were small; secondly, that only treated cancers were recorded; and, thirdly, that only $70 \%$ of reported tumours were confirmed histologically. The small numbers did not allow a fine analysis by other than a few variables and broad subcategories. Treated cancers only were used to determine incidence in this $\widehat{O}$ study. Marks and coworkers showed that at any time $2-3 \%$ of Victorians aged 40 and over have undiagnosed non-melanocytic $\pi$ skin cancer. ${ }^{19}$ This large number of undiagnosed non-melanocytic $\mathbb{\Phi}$ skin cancers will lead to some inaccuracies when trying to determine m the true incidence of non-melanocytic skin cancer, not just the incidence of treated cases.

Included in the survey were all non-melanocytic skin cancers $\stackrel{\text { P }}{+}$ diagnosed clinically. Ideally all tumours should be confirmed histologically, as studies have shown inaccuracies in clinical $\frac{}{\bar{N}}$ diagnoses. ${ }^{24} 25$ Only $70 \%$ of tumours in this series, however, were $\frac{\pi}{\nabla}$ viewed by a pathologist and confirmed histologically. Biopsy is not $\stackrel{\mathbb{Q}}{2}$ always possible for several reasons, including being unacceptably \& expensive for some people. For patients to have a biopsy and then $\vec{\circ}$ have to return to their doctor at a later date for treatment costs time and money. Presumably, therefore, some doctors are confident of $\vec{\omega}$ their ability to diagnose these lesions clinically and find it more cost efficient to treat them without confirmation of the diagnosis.

By utilising our incidence data and applying the age specific rates to the Australian population it is possible to estimate the magnitude $\mathscr{\circ}$ of the public health problem caused by non-melanocytic skin cancer $\dot{ }$ in Australia. Roughly 140000 people have non-melanocytic skin cancer treated each year in Australia. One fifth of these have at least one squamous cell carcinoma, and if the same proportion as that $\omega$ reported by Nixon and coworkers metastasise ${ }^{26}$ around 500 of these $\stackrel{9}{ᄀ}$ people will have a metastasis from this form of non-melanocytic skin $N$ cancer within two years. Each year over 200 Australians die from non-melanocytic skin cancer. ${ }^{27}$ This number of deaths is consistent with the incidence and metastasis rates we have used.

A minimal cost to the community may be attained by multiplying the estimated number of lesions treated each year by the standard $\infty$ fees for consultation and procedures and then adding the standard fees for the pathologist to $70 \%$ of these. This results in an estimated minimum cost of around \$A50000000 each year. This is the figure for non-melanocytic skin cancer alone and does not include the amount required for management of the vastly greater number of people currently being treated for solar keratoses. Other studies in $\stackrel{\mathbb{Q}}{\varrho}$ Australia have shown the prevalence of solar keratoses to be at least $\overline{\vec{z}}$ 10 times that of non-melanocytic skin cancer. ${ }^{17} 19$

It is plain from these figures that further time, money, and $\supset$ effort are necessary to change community behaviour in regard to Australian sunlight. We hope that this will eventually reduce what has become a crucial public health problem related to skin damage and skin cancer in Australia.

We acknowledge the help of Roy Morgan Research Pty Ltd with the conduct of this survey. We thank George Rennie, Damien Jolley, and Spiro 윽 Lecatsas for their statistical skill with various aspects of the design and $N$ analysis.

\section{References}

1 Carmichael GG. A survey of skin cancers and solar keratosis in country areas of Queensland. Med $\mathcal{f}$ Aust 1962;i:395-400.

2 Silverstone H, Campbell CB, Hosking CS, et al. Regional studies in skin cancer. I. North west Queensland. Med f Aust 1963;i:312-5.

3 Silverstone $\mathrm{H}$, Gordon D. Regional studies in skin cancer. II. Wet tropical and sub-tropical coasts $\mathscr{N}$ of Queensland. Med I Aust 1966;ii:733-40.

4 Ten Seldam REJ. Skin cancer in Australia. In: Urbach F, ed. The first international conference on biology of cutaneous cancer. Washington: National Cancer Institute, 1963:153-6. (NCI
monograph No 10.)

5 Silverstone $\mathrm{H}$, Searle JHA. The epidemiology of skin cancer in Queensland: the influence of perstone $\mathrm{H}$, Searle JHA. The epidemiology of skin cancer

6 Nie NH. SPSS-X user's guide. New York: McGraw-Hill, 1983.

7 Payne CD, ed. The GLIM system; release 3.77 manual. London: Royal Statistical Society, 1986. 8 Doll R. Comparisons between registries; age-standardized rates. In: Waterhouse J, Muir C, Correa P, Powell J, eds. Cancer incidence in five continents. Vol 3. Berlin: Springer Verlag, o 1979:453-9.

9 Stukonis MK. Cancer incidence cumulative rates-international comparisons. Lyon: International Agency for Research on Cancer, 1978:25. (Technical report 78/002.) 
10 Armitage P. Statistical methods in medical research. Oxford: Blackwell Scientific, 1971:370 11 Giles GG, Armstrong BKA, Smith L, eds. Cancer in Australia 1982. Melbourne: Anti-Cance Council of Victoria, 1987 .

12 Scotto J, Fears TR, Fraumeni JF. Incidence of nonmelanoma skin cancer in the United States. Washington: US Department of Health and Human Services, 1983:4-6. (National Institutes of Health publication 83-2433.)

13 Fitzpatrick TB, Sober AJ. Sunlight and skin cancer. N Engl f Med 1985;313:818-20.

14 Laerum OD, Iverson OH, eds. Biology of skin cancer (excluding melanomas). Geneva: Union International Contra le Cancrum, 1981:58-86. (Technical report series 63.)

15 Waterhouse J, Muir C, Shanmugaratnam K, Powell J, eds. Cancer incidence in five continents. Vol 4. Lyon: International Agency for Research on Cancer, 1982:732-3.

16 Levi FG, Chapallaz S. Les cancers de peau dans le canton de Vaud. Schweizerische Rundschau für Medizin Praxis 1981;70:1120-30.

17 Goodman GJ, Ponsford MW, Pakes W, et al. Non melanotic skin cancer and solar keratoses in Victoria; clinical studies II. Australas $\mathcal{F}$ Dermatol 1984;25:103-6.

18 Macdonald EJ. Epidemiology of skin cancer. F Invest Dermatol 1959;32:379-82.

19 Marks R, Ponsford MW, Selwood TS, et al. Non melanotic skin cancer and solar keratosis in Victoria. Med f Aust 1983;ii:619-22.
20 Morison WL, Paul BS, Parrish JA. Indomethacin and UVA erythema. $f$ Invest Dermatol 1977;68:130-3.

21 Lynch FW. Incidence of cutaneous cancer in Minnesota. Cancer 1970;25:83-91.

22 Barton IJ, Paltridge GW. The Australian climatology of biologically effective UVR. Australas Dermatol 1979;20:68-74.

23 Holman CD, Armstrong BK. Cutaneous malignant melanoma and indicators of total accumulated exposure to the sun: an analysis separating histogenetic types. Fournal of the National Cancer Institute 1984;73:75-82.

24 Lightstone AC, Kopf AW, Garfinkel L. Diagnostic accuracy-a new approach to its evaluation. Arch Dermatol 1961;91:497-502.

25 Ponsford MW, Goodman G, Marks R. The prevalence and accuracy of diagnosis of non melanotic skin cancer in Victoria. Australas $\mathcal{F}$ Dermatol 1983;24:79-82.

26 Nixon R, Dorevitch AP, Marks R. Squamous cell carcinoma of the skin: accuracy of clinical diagnosis and outcome of follow-up in Australia. Med $\mathcal{F}$ Aust 1986;144:235-8.

27 Holman CDJ, Armstrong BK. Cancer mortality trends in Australia 1910-1979. Perth: Cance Council of Western Australia, 1982:283-92.

(Accepted 6 October 1987)

\section{SHORT REPORTS}

\section{Reduced neonatal mortality from infection after introduction of respiratory monitoring}

Lancefield group B streptococci are an important cause of neonata infection. In the United States the incidence of neonatal infection due to this organism has been estimated at two to three cases per 1000 live births, whereas in the United Kingdom it has been reported as being about one tenth of this $(2 \cdot 9 / 10000){ }^{2}$ Mortality from neonatal septicaemia caused by group B streptococci is between $20 \%$ and $50 \%{ }^{3}$ Since 1980 we have regularly monitored the respiratory rate of newborn babies as an increased rate is a frequent early sign of infection. ${ }^{3} \mathrm{We}$ assessed the effect of monitoring on the mortality of neonates from septicaemia due to group B streptococci.

\section{Patients, methods, and results}

The respiratory rate of each infant in the postnatal ward was recorded every hour for the first 12 hours and every two hours for the next 24 hours by a device that did not disturb the infant. ${ }^{4}$ Neonates whose respiratory rate exceeded 60 breaths/minute for more than one hour were transferred to the special care baby unit. There, blood cultures were collected and babies were treated empirically with antibiotics if tachypnoea persisted for more than two hours. Neonates already in the special care baby unit were managed similarly.

Microbiological records for the seven years 1980-6 were reviewed, and the notes of all infants for whom group B streptococci had been isolated from blood cultures were examined. During this period 21942 live births were recorded 19 neonates developed septicaemia of early onset caused by group B streptococci, of whom three had meningitis; one baby was readmitted at 17 days with meningitis of late onset (table)

Tachypnoea was the first and initially the only sign of infection in six neonates. An increased respiratory rate was detected in the postnatal ward in four babies (cases 1-4) and was the only reason for transfer to the special care baby unit. One baby (case 1) eventually developed a fever, but antibiotic treatment had been started two hours before. Two babies (cases 2 and 3 ) fed poorly and had prolonged tachypnoea. One baby (case 4) developed tachypnoea alone, which resolved spontaneously within two hours of transfer; antibiotic treatment was not started until the baby developed fever and an increased respiratory rate at 3 days of age, by which time group B streptococci had been isolated from blood cultures. Two neonates (cases 5 and 6 ) were already in the special care baby unit because of prematurity and had required intubation for five and 25 minutes, respectively. Neither developed a fever or showed other signs of infection until at least six hours after antibiotics were started. Tachypnoea was observed in a further seven neonates (cases 7-13), but blood had already been collected for culture and antibiotic treatment started for other reasons (table). Early tachypnoea was not observed in four babies (cases 14-17) who had infection of early onset and in whom group B streptococci were isolated from blood cultures. A further two babies (cases 18 and 19) developed septicaemia due to group B streptococci while being ventilated because of apnoea.

Details of infants in whom group $B$ streptococci were isolated from blood cultures during 1980-6

\begin{tabular}{|c|c|c|c|c|c|c|c|c|c|}
\hline \multirow[b]{2}{*}{$\begin{array}{l}\text { Case } \\
\text { No }\end{array}$} & \multirow{2}{*}{$\begin{array}{c}\text { Gestational } \\
\text { age } \\
\text { (weeks) }\end{array}$} & \multirow[b]{2}{*}{$\begin{array}{l}\text { Birth weight } \\
\text { (g) }\end{array}$} & \multirow{2}{*}{$\begin{array}{c}\text { Age when } \\
\text { tachypnoea } \\
\text { noted } \\
\text { (h) }\end{array}$} & \multirow{2}{*}{$\begin{array}{l}\text { Age when } \\
\text { penicillin } \\
\text { started } \\
\text { (h) }\end{array}$} & \multirow[b]{2}{*}{ Associated features } & \multicolumn{3}{|c|}{ Group B streptococci isolated from: } & \multirow[b]{2}{*}{ Outcome } \\
\hline & & & & & & $\begin{array}{l}\text { Cerebrospinal } \\
\text { fluid }\end{array}$ & $\begin{array}{c}\text { Gastric } \\
\text { aspirate }\end{array}$ & $\begin{array}{l}\text { Surface sites } \\
(\mathrm{No})\end{array}$ & \\
\hline \multicolumn{10}{|c|}{ Tachypnoea was first sign of infection } \\
\hline $\begin{array}{l}1 \\
2 \\
3 \\
4 \\
5 \\
6\end{array}$ & $\begin{array}{l}39 \\
41 \\
39 \\
39 \\
33 \\
32\end{array}$ & $\begin{array}{l}3300 \\
3900 \\
3400 \\
3000 \\
1800 \\
2000\end{array}$ & $\begin{array}{c}27 \\
5 \\
5 \\
6 \\
1 / 4 \\
1\end{array}$ & $\begin{array}{c}34 \\
6 \\
8 \\
52 \\
1 / 2 \\
2\end{array}$ & $\begin{array}{l}\text { Fever } \\
\text { None } \\
\text { None } \\
\text { None } \\
\text { None } \\
\text { None }\end{array}$ & $\begin{array}{l}+ \\
- \\
- \\
- \\
-\end{array}$ & $\begin{array}{l}+ \\
- \\
- \\
+ \\
+ \\
+\end{array}$ & $\begin{array}{l}+(3) \\
+(1) \\
+(3) \\
+(3) \\
+(2) \\
+(3)\end{array}$ & $\begin{array}{l}\text { Recovered } t \\
\text { Recovered } t \\
\text { Recovered } t \\
\text { Recovered } t \\
\text { Recovered } \\
\text { Recovered }\end{array}$ \\
\hline \multicolumn{10}{|c|}{ Tachypnoea observed after blood cultures taken } \\
\hline $\begin{array}{r}7 \\
8 \\
9 \\
10 \\
11 \\
12 \\
13\end{array}$ & $\begin{array}{l}34 \\
29 \\
40 \\
40 \\
40 \\
37 \\
36\end{array}$ & $\begin{array}{l}1600 \\
1500 \\
3700 \\
3700 \\
4000 \\
3600 \\
2600\end{array}$ & $\begin{array}{l}15 \\
1 / 4 \\
24 \\
15 \\
7 \\
3 \\
72\end{array}$ & $\begin{array}{l}5 \\
1 / 4 \\
20 \\
14 \\
2 \\
2 \\
2\end{array}$ & $\begin{array}{l}\text { Fever } \\
\text { Respiratory distress, hypotension } \\
\text { Fever } \\
\text { Fever } \\
\text { Maternal fever } \\
\text { Maternal fever } \\
\text { Maternal fever }\end{array}$ & $\begin{array}{l}- \\
- \\
- \\
- \\
-\end{array}$ & $\begin{array}{l}+ \\
+ \\
+ \\
+ \\
+ \\
+ \\
+\end{array}$ & $\begin{array}{l}+(3) \\
+(1) \\
+(3) \\
+(3) \\
+(3) \\
+(3) \\
+(3)\end{array}$ & $\begin{array}{l}\text { Recovered } \\
\text { Died aged } 8 \mathrm{~h} \\
\text { Recovered } \\
\text { Recovered } \\
\text { Recovered } \\
\text { Recovered } \\
\text { Recovered }\end{array}$ \\
\hline \multicolumn{10}{|c|}{ Tachypnoea not observed } \\
\hline $\begin{array}{l}14 \\
15 \\
16 \\
17 \\
18 \ddagger \\
19 \ddagger\end{array}$ & $\begin{array}{l}38 \\
37 \\
35 \\
30 \\
40 \\
30\end{array}$ & $\begin{array}{l}3300 \\
2500 \\
1800 \\
1400 \\
3500 \\
1500\end{array}$ & & $\begin{array}{c}64 \\
70 \\
1 \\
3 \\
1 \\
1 / 4\end{array}$ & $\begin{array}{l}\text { Fever } \\
\text { Fever, hypotonia } \\
\text { Maternal fever } \\
\text { Hypotension } \\
\text { Apnoea, fever } \\
\text { Apnoea }\end{array}$ & $\begin{array}{l}+ \\
+ \\
- \\
- \\
-\end{array}$ & $\begin{array}{l}- \\
\overline{+} \\
+ \\
- \\
-\end{array}$ & $\begin{array}{l}+(3) \\
+(3) \\
+(3) \\
+(3) \\
+(1) \\
+(3)\end{array}$ & $\begin{array}{l}\text { Recovered } \\
\text { Recovered } \\
\text { Recovered } \\
\text { Recovered } \\
\text { Recovered } \\
\text { Recovered }\end{array}$ \\
\hline \multicolumn{10}{|c|}{ Late onset disease due to group $B$ streptococci } \\
\hline 20 & 37 & 3300 & & 17 days & Fever & + & - & $+(1)$ & Recovered \\
\hline
\end{tabular}

*Two hours after start of antibiotic treatment. 